\title{
Identifikasi Critical Success Factor pada Hubungan Kerjasama Pemasok dalam Persaingan Penyediaan Material Proyek Konstruksi Jalan Tol Ngawi-Kertosono
}

\author{
Vega, L.D., Negoro, N.P., dan Ardiantono, D.S. \\ Departemen Manajemen Bisnis, Fakultas Bisnis dan Manajemen Teknologi, Institut Teknologi \\ Sepuluh Nopember (ITS) \\ e-mail: lidyadwivega@gmail.com
}

\begin{abstract}
Abstrak-Pembangunan konstruksi jalan tol Trans Jawa ruas Ngawi Kertosono melibatkan tiga General Contractor (GC) serta tujuh subkontrator. GC bekerja sebagai perusahaan konsorsium dan subkontraktor sebagai penyedia pasokan material. Hubungan yang harmonis antara GC dengan subontraktor akan tercipta apabila subkontraktor mampu memenuhi segala permintaan dan tuntutan GC. Kondisi di lapangan yang tidak selalu mendukung pencapaian permintaan GC menuntut para subkontraktor untuk melakukan strategi yang optimal. Salah satunya yaitu melakukan kerjasama dengan subkontraktor lain (horizontal cooperation) untuk memenuhi tuntutan GC. Penelitian ini menggunakan metode Analytical Hierarchy Process (AHP) untuk melakukan perbandingan pembobotan tiap indikator. Responden dalam penelitian ini adalah seluruh subkontraktor dalam proyek konstruksi jalan tol NgawiKertosno. Hasil penelitian menunjukkan bahwa kualitas material, keterlibatan masyarakat, harga yang sesuai, komitmen terhadap proyek, serta pemenuhan sarana transportasi merupakan CSF yang mendasari hubungan kerjasama horizontal pada proyek konstruksi jalan tol Ngawi-Kertosono.
\end{abstract}

Kata Kunci-Analytical Hierarchy Process, Project Success Factor, Horizontal Cooperation, Subkontraktor.

\section{PENDAHULUAN}

$\mathrm{H}$ UBUNGAN kerjasama dalam proyek konstruksi jalan tol Trans Jawa ruas Ngawi Kertosono melibatkan perusahaan konsorsium sebagai General Contractor (GC) dan subkontraktor sebagai penyedia pasokan material. Untuk menciptakan kinerja yang optimal pada kerjasama GC dan subkontraktor, hubungan antara seluruh anggota harus diatur secara jelas dan detail, termasuk pada proyek jalan tol. Hal ini dikarenakan hubungan antara GC dan subkontraktor seringkali mengalami ketegangan dan rentan terhadap perselisihan akibat adanya rasa ketidakadilan dan kesalahpahaman mengenai kebutuhan masing-masing [1]. Oleh karena itu, GC akan membuat metode kontrak dengan para subkontraktor yang mana akan memberikan insentif baru untuk memperbaiki kualitas konstruksi. Kontrak yang muncul ini akan bertumpu pada pengambilan keputusan strategi pemanfaatan sumber daya optimal yang meminimalkan biaya konstruksi dan waktu namun tetap memaksimalkan kualitasnya [2]. Hasil dari kontrak yang ditetapkan GC kepada subkontraktor diharapkan mampu menciptakan perasaan aman dan tidak menimbulkan efek samping sosial (lingkungan) yang bersifat negatif. Dari pernyataan tersebut dapat dikatakan bahwa biaya, waktu, kualitas, keamanan, dan lingkungan merupakan faktor-faktor yang penting untuk diperhatikan [3].

Kendala yang terjadi di lapangan sering kali memperparah ketidaksempurnaan akan pemenuhan tuntutan GC terhadap subkontraktor. Faktor waktu dan biaya memiliki keterkaitan yang erat dalam kesuksesan proyek yaitu saat cuaca dan akses jalan yang buruk menyebabkan tidak tercapainya target waktu penyelesaian, padahal dengan adanya keterlambatan itu subkontraktor akan dirugikan dalam sisi penyewaan alat berat, sehingga keadaan ini menambah beban pada biaya operasional dan perencanaan keuangan proyek yang telah dibuat di awal akan membengkak atau mengakibatkan overbudget. Kondisi keuangan yang buruk dapat menyebabkan subkontraktor tidak memiliki cukup dana guna memenuhi pemintaan pasokan material dengan kualitas tinggi, padahal permintaan GC terhadap kualitas material atau pemenuhan faktor kualitas tidak dapat diganggu gugat. Di sisi lain, rumitnya perijinan eksplorisasi alam sebagai sumber pasokan material serta sulitnya mendapatkan respon positif atau ijin dari seluruh masyarakat setempat membuat subkontraktor kesulitan memenuhi faktor lingkungan. Kendala-kendala yang sulit diatasi ini akan menimbulkan ketidakpercayaan GC terhadap kinerja subkontraktor, sehingga faktor keamanan tidak dapat terpenuhi dengan kata lain pemenuhan faktor biaya, waktu, kualitas, keamanan, dan lingkungan tidak akan sempurna.

Strategi jaringan bisnis dan terutama kerjasama dalam bidang logistik merupakan salah satu kemungkinan untuk menyelesaikan permasalahan yang ada [4]. Selain itu kerjasama dalam bidang ini juga dapat menjadi ajang bertukar informasi, teknologi, serta melebarkan pangsa pasar. Adanya manfaat yang dihasilkan oleh penggabungan perusahaan akan menciptakan kondisi kerjasama yang cukup rumit baik dari segi keuangan maupun manajemen. Penggabungan dua perusahaan terkadang tidak diimbangi dengan pemahaman akan pengaruh-pengaruh dari tiap kegiatan bisnis yang akan 
dilakukan terhadap perusahaan individu tersebut. Oleh karena itu setiap

Table 1.

Project Success Factors Pada Kerjasama Horizontal

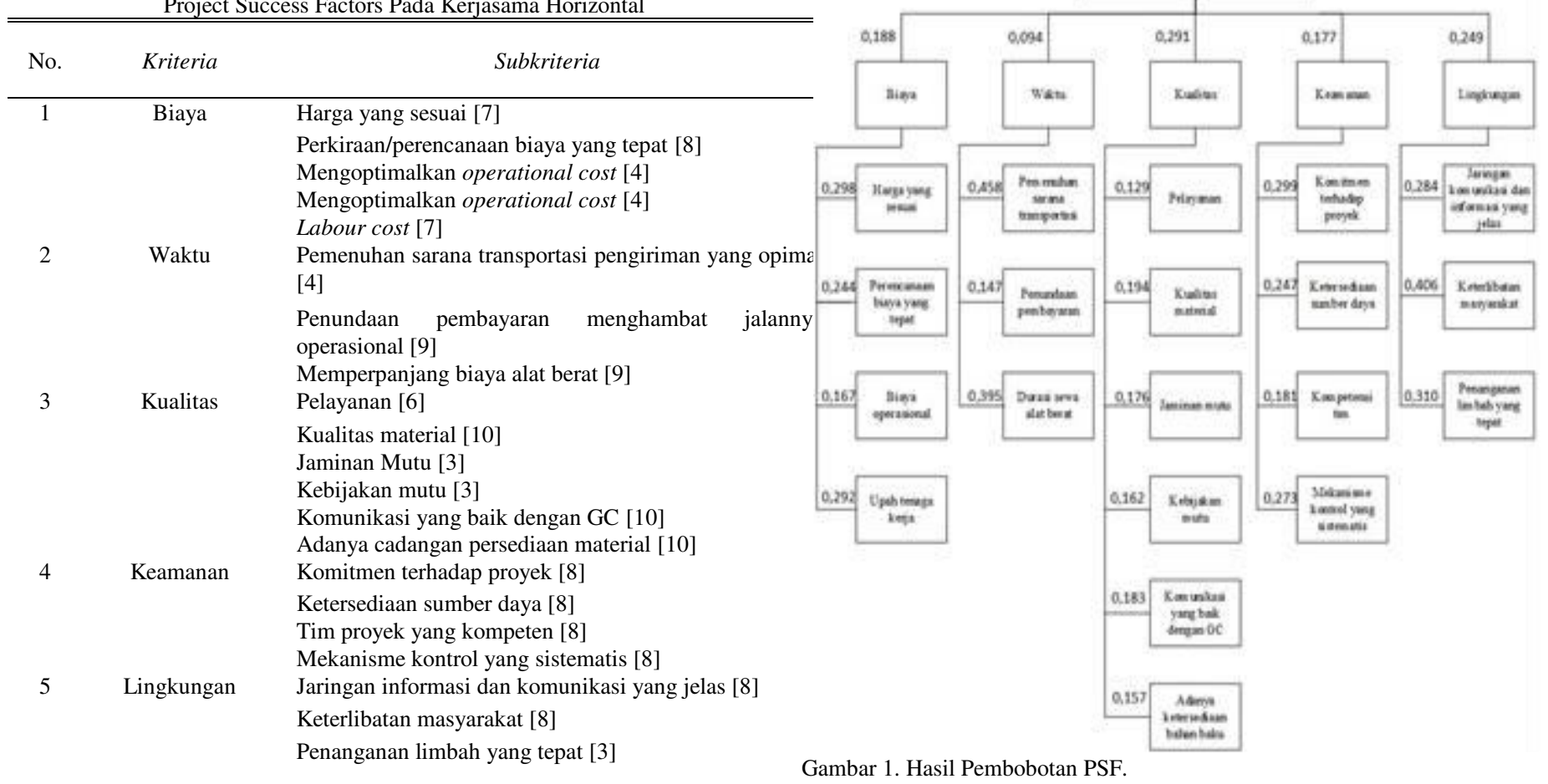

subkontraktor harus memahami Project Success Factor (PSF) dan Critical Success Factor (CSF). PSF adalah faktor yang dirasa penting dari suatu proyek [5] dan CSF merupakan faktor apa yang paling kritis serta wajib diperhatikan dalam PSF [6]. PSF dan CSF akan mendasari pemilihan hubungan kerjasama yang akan diterapkan. Faktor-faktor apa saja yang mendasari hubungan kerjasama merupakan bahasan dari penelitian ini.

\section{METODE PENELITIAN}

Dalam penelitian ini dilakukan pembobotan guna mereduksi PSF menjadi Critical Success Factor (CSF). Langkah pertama dalam penelitian ini adalah dengan melakukan studi literatur untuk menemukan PSF yang sesuai dengan proyek konstruksi jalan tol ruas Ngawi Kertosono. Setelah menemukan PSF yang terdiri dari lima perspektif dan 20 subkriteria, maka dilakukan penyusunan hirarki AHP yang selanjutnya dilanjutkan dengan pembuatan kuesioner AHP sebagai instrumen pembobotan. Setelah proses pembobotan selesai, data diolah menggunakan software Expert Choice. Hasil dari pembobotan dari masingmasing perspektif akan digunakan sebagai dasar evaluasi hubungan kerjasama dan bobot nilai tertinggi dari masingmasing subkriteria dari satu perspektif ditetapkan sebagai CSF.

\section{HASIL DAN DISKUSI}

\section{A. Penentuan ahli sebagai responden}

Penentuan ahli sebagai responden kuesioner dipilih berdasarkan pihak yang berkompeten dalam proyek pembangunan konstruksi jalan tol ruas Nganjuk Kertosono.
Total ahli yang dijadikan responden dalam penelitian ini adalah tujuh orang dengan memperhatikan kompetensi jabatannya. Dari tujuh responden empat orang merupakan pemilik subkontraktor, satu orang merupakan top manager dalam subkontraktor, dan dua orang merupakan koordinator lapangan sekaligus merangkap quality control

\section{B. Penentuan Project Success Factor}

Proses penentuan PSF yakni melalui studi literatur yang bertujuan untuk mencari faktor keberhasilan yang sesuai dengan pembagunan konstruksi jalan tol Ngawi Kertosono. Pada bagian ini peneliti menetapkan 5 perspektif (kriteria) dalam Project Success Factor yaitu biaya, waktu, kualitas, kemanan dan lingkungan yangmana masing-masing kriteria memiliki sub-kriteria. Pada Tabel 1 ditunjukkan apa saja kriteria dan aspek dari project success factor yang akan direduksi menjadi critical success factor.

\section{Pembobotan Project Success Factor}

Berdasarkan pada hasil kuesioner yang telah diberikan kepada responden, maka didapatkan bobot tingkat kepentingan pada masing-masing kriteria dan sub-kriteria. Pembobotan dilakukan dengan menggunakan software Expert Choice. Gambar 1 menunjukan hasil pembobotan dari PSF.

\section{Penentuan Critical Success Factor}

Identifikasi critical success factors dilakukan berdasarkan pada hasil pembobotan yang dilakukan oleh ahli dalam konstruksi pembangunan jalan tol ruas Ngawi Kertosono menggunakan metode AHP. Penentuan critical success factors ditentukan dari nilai sub-kriteria dari masing-masing perspektif. Dari hasil pembobotan yang dilakukan, didapatkan 
CSF dari masing-masing lima kriteria yang telah ditentukan. Pada kriteria biaya, sub-kriteria harga yang sesuai menjadi CSF dengan nilai bobot 0,298 . Pada kriteria waktu, subkriteria pemenuhan sarana transportasi menjadi CSF dengan nilai bobot 0.458 . Pada kriteria kualitas, sub-kriteria kualitas material menjadi CSF dengan nilai bobot 0.194. Pada kriteria keamanan, sub-kriteria komitmen terhadap proyek menjadi CSF dengan nilai bobot 0.299. Pada kriteria lingkungan, subkriteria keterlibatan masyarakat menjadi CSF dengan nilai bobot 0.406 .

\section{E. Rasio Inkonsistensi}

Rasio inkonsistensi dapat dikatakan kompeten dan dapat diterima apabila kurang atau sama dengan 0,1. Dari tujuh ahli, didapatkan rasio inconsistency keseluruhan di bawah nilai maksimum yaitu 0.10 , hal tersebut berarti bahwa data yang diberikan oleh ahli konsisten dan dapat diandalkan. Tabel 2 menunjukkan rasio inkonsistensi pada penelitian ini.

Tabel 2.

Rasio Inkonsistensi Pembobotan CSF

\begin{tabular}{ccc}
\hline \hline Ahli & $\begin{array}{c}\text { Indeks } \\
\text { inconsistency } \\
\text { individu }\end{array}$ & $\begin{array}{c}\text { Indeks } \\
\text { inconsistency } \\
\text { keseluruhan }\end{array}$ \\
\hline Subkontraktor 1 & 0,08 & \\
Subkontraktor 2 & 0,08 & \\
Subkontraktor 3 & 0,04 & \\
Subkontraktor 4 & 0,02 & 0,00608 \\
Subkontraktor 5 & 0,04 & \\
Subkontraktor 6 & 0,09 & \\
Subkontraktor 7 & 0,06 & \\
\hline \hline
\end{tabular}

\section{F. Analisis perbandingan antar faktor}

Pada penelitian ini terdapat lima kriteria berdasarkan studi literatur yang ditetapkan sebagai kriteria-kriteria project success factor dalam proyek pembangunan konstruksi jalan tol. Lima kriteria tersebut adalah biaya, waktu, kualitas, keamanan, dan lingkungan. Kelima kriteria ini merupakan satu kesatuan yang harus dipenuhi oleh subkontraktor dalam melaksanakan kewajibannya terhadap general contractor (GC). Kriteria mana yang harus didahulukan atau kriteria mana yang sulit dipenuh apabila subkontraktor merupakan perusahaan individu? Hasil dari instumen penelitian yang digunakan peneliti dalam menjawab pertanyaan-pertanyaan tersebut yang berupa kuesioner kepada tujuh ahli akan dibahas dalam bagian ini.

Kriteria dengan bobot tertinggi jatuh kepada kualitas dengan bobot penilaian 0,291. Kriteria dengan bobot tertinggi kedua adalah lingkungan dengan bobot penilaian 0,249. Selanjutnya kriteria dengan bobot tertinggi ketiga adalah biaya dengan bobot penilaian 0,188 . Keamanan berada di posisi keempat yaitu dengan bobot penilaian 0,177 dan penilaian bobot terendah atau yang berada pada posisi kelima adalah waktu dengan bobot penilaian 0,094.

G. Analisis Critical Success Factor yang Mendasari Hubungan Kerjasama antara Pemasok Material Proyek Konstruksi Jalan Tol hubungan kerjasama horizontal

Dari hasil pengolahan data secara keseluruhan dengan menggunakan metode AHP, maka diperoleh suatu hasil sebagai CSF yang Mendasari Hubungan Kerjasama antara Pemasok Material Proyek Konstruksi Jalan Tol. Tabel 3 menunjukkan CSF berdasarkan masing-masing perspektif.

Tabel 3.

Daftar CSF

\begin{tabular}{lll}
\hline \hline Prioritas & \multicolumn{1}{c}{ Perspektif } & \multicolumn{1}{c}{ CSF } \\
\hline 1 & Kualitas & Kualitas material \\
2 & Lingkungan & Keterlibatan masyarakat \\
3 & Biaya & Harga yang sesuai \\
4 & Keamanan & Komitmen terhadap proyek \\
5 & Waktu & Pemenuhan sarana \\
& & transportasi \\
\hline \hline
\end{tabular}

Tingkat prioritas pada perspektif tersebut berdasarkan nilai bobot tertinggi pada setiap perspektif dan masing-masing CSFnya [17]. CSF yang memiliki prioritas tertinggi yaitu kualitas material berarti hal ini merupakan aktivitas yang paling diperhitungkan dalam landasan hubungan kerjasama. Dengan adanya kerjasama horizontal, harapannya faktor kualitas material akan terpenuhi mengingat kualitas material merupakan CSF dengan prioritas pertama. Setelah pemenuhan kualitas material, penanganan subkontraktor mengenai lingkungan menjadi prioritas kedua. CSF dari perspektif lingkungan adalah keterlibatan masyarakat. Keterlibatan masyarakat ini apabila tidak ditangani secara baik dapat menghambat jalannya proyek. Hal ini tercermin dalam perilaku masyarakat yang tidak serta merta menyetujui adanya aktivitas proyek di daerah sekitar pemukiman mereka. Pada pelaksanaan kegiatan kerja, subkontraktor dituntut untuk membangun jalan sendiri yang memadai guna akses alat transportasinya. Apabila masyarakat tidak setuju adanya pembangunan akses jalan, maka berarti subkontraktor akan kesulitan dalam memasok materialnya. Tidak semua pihak dapat mengatasi permasalahan yang berkaitan dengan masyarakat oleh karena itu dengan adanya hubungan kerjasama antara subkontraktor, maka permasalahan ini dapat diatasi secara bersama-sama.

CSF pada prioritas ketiga adalah harga yang sesuai dari perspektif biaya. Harga yang sesuai disini tidak hanya ditujukan untuk kepuasan GC saja melainkan akan membawa dampak besar bagi keuntungan subkontraktor sendiri. Apabila subkontraktor melakukan hubungan kerjasama, maka pemenuhan biaya investasi, beban akan biaya operasional dapat ditanggung bersama. Selain itu apabila melakukan hubungan kerjasama, bagi subkontraktor-subkontraktor yang memiliki kuori kecil dapat bersama-sama membeli kuori yang jauh lebih besar. Hal-hal teersebut dapat menekan biaya material sehingga subkontraktor dapat memberikan harga yang sesuai dengan GC, dimana GC mendapatkan harga murah dan subkontraktor mendapatkan profit yang maksimal.

CSF pada prioritas keempat adalah komitmen terhadap proyek. Penggabungan dua tim dengan adanya hubungan kerjasama membuat komitmen terhadap proyek menjadi salah satu kunci keberhasilan menjalani hubungan kerjasama. Tanpa adanya komitmen terhadap proyek, ditakutkan akan terjadinya perpecahan dalam hubungan kerjasama selama proyek masih berlangsung. Perpecahan ini tidak hanya merusak hubungan kerjasama antara subkontraktor, melainkan dengan GC juga. Oleh karena itu komitmen terhadap proyek penting untuk dimiliki mulai dari masing-masing individu subkontraktor. 
CSF kelima adalah pemenuhan sarana transportasi. Sarana transportasi yang memadai sangat diperlukan dalam melakukan kegiatan pasokan material. Padahal tidak semua subkontraktor memiliki jaringan yang luas akan pihak penyedia sarana trasnportasi (sewa truk), sedangkan pabila tidak terpenuhinya sarana transportasi (truk pengangkut material) maka kiriman pasokan material tidak tersalurkan sesuai target permintaan. Oleh sebab itu dengan adanya hubungan kerjasama diharapkan mampu mengatasi permasalahan ini.

\section{KESIMPULAN}

Kesimpulan dari penelitian ini yaitu Critical Success Factor (CSF) pada perspektif kualitas adalah kualitas material, perspektif lingkungan adalah keterlibatan masyarakat, perspektif biaya adalah harga yang sesuai, perspektif keamanan adalah komitmen terhadap proyek dan perspektif waktu adalah pemenuhan sarana transportasi.

\section{DAFTAR PUSTAKA}

[1] J. Proctor, "Golden Rule of Contractor-Subcontractor Relations," Int. J. Pract. Period. Struct. Des. Constr., vol. 1, no. 1, pp. 12-14,
1996.

[2] K. . Rayes and A. Kandil, "Time-Cost-Quality Trade-Off Analysis for Highway Construction," J. Constr. Eng. Manag., vol. 131, no. 4, pp. 477-486, 2005.

[3] J. I. Alzahrani and M. Emsley, "The Impact of Contractors" attributes on construction project success: A post construction evaluation," Int. J. Proj. Manag., vol. 31, pp. 313-322, 2013.

[4] R. Leitner, Meizer, F. Prochazka, and W. Sihn, "Structural concepts for horizontal cooperation to increase efficiency in logistics," $J$. Manuf. Sci. Technol., vol. 4, no. 3, pp. 332-337, 2011.

[5] Z. Hatus and M. Skitmore, "Evaluating contractor prequalification data: selection criteria and project success factors," J. Constr. Manag. Econ., vol. 15, no. 2, pp. 129-147, 1997.

[6] A. Chan and et al, "Exploring Critical Success Factors for Partnering in Construction Projects," J. Constr. Eng. Manag., vol. 131, no. 2, pp. 188-198, 2004.

[7] H. Soo Lee, "Transaction-Cost-Based Selection of Appropriate General Contractor-Subcontractor Relationship Type," J. Constr. Eng. Manag., vol. 135, no. 11, pp. 1232-1240, 2009.

[8] L. D. Nguyen, S. . Ogunlana, and D. T. X. Lan, "A study on project success factors in large construction projects in Vietnam," J. Eng. Constr. Archit. Manag., vol. 11, no. 6, pp. 404-413, 2004.

[9] H. Xiao and D. Proverbs, "Construction time performance: an evaluation of contractors from Japan, the UK and the US," J. Eng. Constr. Archit. Manag., vol. 9, no. 2, pp. 81-89, 2002.

[10] A. Al-Hammad, "Factors affecting the relationship between contractors and their sub-contractors in Saudi Arabia," J. Build. Res. Inf., vol. 21, no. 5, pp. 269-273, 1993. 